\title{
Modern Development Strategy of Russian Education
}

\author{
Flera Gabdulbarovna Mukhametzyanova ${ }^{1}$, Aleksandr Vladimirovich Morozov ${ }^{2}$, Ramil Ravilovich Khayrutdinov ${ }^{1}$, \\ Yulia Mikhailovna Fedorchuk ${ }^{3} \&$ Rita Rinatovna Aminova ${ }^{1}$ \\ ${ }^{1}$ Department of Historical and Civic Education, Institute of International Relations of Kazan (Volga Region) Federal \\ University, Russia \\ ${ }^{2}$ National Research Centre NITS-2, Federal State Institution Research Institute of the Federal Penitentiary Service of \\ Russia, Russia \\ ${ }^{3}$ Federal State Budgetary Scientific Institution, Institute of Education Management, Russian Academy of Education, \\ Russia \\ Correspondence: Flera Gabdulbarovna Mukhametzyanova, Department of Historical and Civic Education, Institute of \\ International Relations of Kazan (Volga Region) Federal University, Russia. E-mail: florans955@mail.ru
}

Received: September 2, 2020

Accepted: October 22, 2020

Online Published: October 31, 2020

doi:10.5430/ijhe.v9n8p72

URL: https://doi.org/10.5430/ijhe.v9n8p72

\begin{abstract}
In this paper, it was tried to consider the current state of normative support for the development of strategic planning documents in the field of Russian education. The strategy for the development of education (DoE), as an industry document of strategic planning, has not been adopted in the Russian Federation (RF) to date. The article attempts to generalize the developments in this area, considers several international documents and projects of strategies for the development of Russian education (DRE), national strategies focused on them. The analysis of regional strategy for the DoE, which is either component of strategies for socioeconomic development of the region, or separate concepts that are focused on municipal development strategies. Due to the lack of a strategic document at the Federal level, regional development concepts are mostly aimed at solving regional problems in the field of education, at a process approach, and, in fact, are not focused on solving breakthrough problems and taking into account all-Russian and global challenges. It is concluded that the Russian educational system cannot develop effectively in the course of planning only national projects that have their own time horizon; to solve this problem, a strategy for the DRE space is necessary, which can provide guidelines for the development of each educational organization.
\end{abstract}

Keywords: education development strategy, strategic planning documents, strategic objectives, sustainable development indicators, regional strategies, development programs

\section{Introduction}

Ever since man began to strive to identify his surroundings, meet his needs, and facilitate the affairs of life, he began to plan. In the current context of planning to achieve goals, it is essential that any group at the national and transnational levels be left without long-term goals as well as practical solutions to achieve them. It should be noted that strategic planning is more focused on traditional planning as opposed to traditional strategies, which will aim to provide appropriate strategies and apply them. One of the main reasons for the failure of programs and plans in some countries is the lack of importance to the issue of planning, or in other words, its lack of foundation in organizations and institutions. Weakness due to diagnosis or weakness in combining their implementation in the preparation and development of planning systems are among the main reasons for this failure. Regardless of the above, mastery of the analysis of past and present situations makes it possible to predict future events. Making decisions based on these predictions to deal with abnormal events and take advantage of accident opportunities is the same planning that is considered. However, some believe that due to the lack of sufficient information about past events, the possibility of prediction has come and therefore planning is not possible. But it does not make sense that in the presence of existing information, however small, we should not seek to interpret them and visualize future situations with the existence of the same information. Strategic planning is one of the important issues that has received much attention in recent years in many countries. 
In traditional planning methods, the planner first predicts "what will happen in the long run", then makes predictions the basis for decision-making and policy, and finally implements them. In other words, it starts from the current situation and goes into the future, while in the new view of planning, the planner first goes to the horizon of the future and, by appearing on the horizon of the future and observing the present and the future, observes the present and the future .One of the measures that can be considered during the correction of incorrect trends and problems of programs and plans is the examination of strategic plans because it is possible to take a critical look at how to prepare and implement the plan.

Historically, a review of the literature in this field shows that strategic planning became common in the 1960s and 1970s when changes in developments in various scientific, economic, social, and political fields increased. In the following decades, especially with the beginning of the 21 st century and with the emergence of phenomena such as globalization, the amazing development of electronic communications, and rapid technological change, the speed and intensity of these changes increased. Therefore, strategic planning, which was based on the analysis of currents and determining the future perspective, became more necessary and in addition to economic areas, also penetrated into cultural and educational areas. As a result, extensive research has been conducted in the areas of strategic planning, strategic management and strategic thinking.

Most countries are committed to creating social welfare and improving the living standards of their Egyptian people. As a result, the question facing planners and policymakers in these countries is how to serve the social interests of the people without holding back economic growth? In the meantime, the question that arises is whether any country should strive to improve social development, which is measured by social indicators, or focus solely on economic growth and delay the provision of basic public needs? Today, the concept of socioeconomic development is much more important than development itself in scientific circles, and many societies refer to it as the most important model of progress. Many believe that economic development and social development are two sides of the same coin. This factor has led to the consideration of socio-economic development in many studies.

Strategic planning is the basis for the development of any socioeconomic facility. The destruction of the planned economy led to the Concept of short-term planning has emerged. At the same time, it is impossible to develop such territory as the Russian Federation (hereinafter - RF) without strategic development plans. In 2014, Federal Law No. 172-FZ "On Strategic Planning in the RF" (Federal Law dated June 28, 2014, No. 172-FZ "On Strategic Planning in the $\mathrm{RF}$ ) was adopted; it has created a regulatory framework for strategic planning in the RF. The law implements the Concept of coordinating state and municipal strategic management in conjunction with budgetary policy.

The sphere of education is the basic and critical branch of the national economy, and therefore, several strategic documents of different levels can be identified concerning it:

- Decree of the President of the Russian Federation (PRF) dated May 7, 2018 No. 204 sets a benchmark for medium-term planning in all spheres of the economy, including education (Decree of the PRF dated January 16, 2017 No. 13);

- Determination of the priorities of the education system for this period is carried out within the framework of the National Project "Education" (Passport of the national project design "Education"), the state program of the RF "Development of Education"(DoE) (Decree of the Government of the Russian Federation (GRF) dated December 26, 2017 No. 1642), and the state program of the RF "Scientific and technological development of the RF" (Resolution of the GRF dated March 29, 2019 No. 377).

Planning to achieve the goals stated in these strategic documents is supported by the budget forecast of the RF for the period up to 2036. Following the budget forecast of the RF for the period up to 2036, expenditures for the state program "DoE" in 2017 and 2018 were 450.1 and 560.1 billion roubles, respectively, and from 2019 to 2024 they will not go beyond 200 billion roubles (Order of the GRF dated March 29, 2019, No. 558-r).

The general vector of development of the education system is set in strategic planning documents worked out within the framework of goal-setting at the federal level, such as the Concept of long-term socioeconomic development of the RF for the period up to 2020 (Order of the GRF dated November 17, 2008 No. 1662-r), the National Security Strategy of the RF (Decree of the PRF dated December 31, 2015 No. 683), the Strategy for the Spatial Development of the RF at period until 2025 (Order of the GRF dated 13.02.2019 No. 207-r), and is annually specified in the messages of the PRF to the Federal Assembly of the RF.

Strategic documents for the period 2020-2024 are being updated taking into account the message of the PRF to the Federal Assembly of the RF dated January 15, 2020, and the list of his instructions (Presidential Address to the Federal 
Assembly of the RF dated 15.01.2020). Within the framework of the basic version of the forecast, it is planned to achieve the main indicators provided for by state programs and the national project "Education" in the period up to 2024. There is a gap in the system of strategic documents, i.e. the absence of a sectoral strategy for the DoE in the RF, which should take into account the current program and strategic forms of a higher level.

Discussions on the development strategy of the Russian education system were launched in 1998. In 2000, the National Doctrine for the Development of Russian Education (DRE) was adopted; it was a declarative legal act showing the main directions of state policy in the field of education (Decree of the GRF dated 04.10.2000 No. 751). The doctrine was developed by a group of experts from the Committee on Education and Science in the State Duma, the Committee on Educational and Environmental Issues in the Federation Council, the Ministry of Education and the Russian Academy of Education. It was approved in January 2000 by the All-Russian Congress of Education Workers. In 2010, on the opening day of the Teacher's Year in Russia, the PRF, D.A. Medvedev approved the National Educational Initiative "Our New School" and then at a meeting of the Council for the Implementation of Priority National Projects and Demographic Policy he instructed the government to submit an annual summary report on the implementation of the initiative (National educational initiative "Our New School") (Ilyina et al., 2019).

The main directions of the initiative for the development of general education are:

- Transition to new educational standards;

- Development of a support system for talented children (Morozov, 2018);

- Improvement of the teaching staff (Morozov, 2019);

- Development and implementation of professional standards, including the professional standard for heads of a general education organization (Morozov, 2019; Morozov, 2019);

- Changing school infrastructure and expanding school autonomy;

- Formation of a personnel reserve system for heads of educational organizations (Neustroev \& Fedorchuk, 2018);

- Innovative models for the professional development of the head of an educational organization (Fedorchuk et al., 2017), etc.

\section{Methods}

Since 2010, strategic forecasting started to apply foresight technologies, which are successfully used in the countries of the European Union. Thus, in 2010, the Childhood 2030 foresight was developed, which was perceived ambiguously by the Russian public. Since 2012, foresight projects such as Education 2030 (Roadmap "Education 2030") and others have been considered. These projects were developed by the Agency for Strategic Initiatives to Promote New Projects, the Moscow School of Management "Skolkovo" and the National Research University Higher School of Economics. The main points were outlined in the report "The future of education: a global agenda" (Luksha \& Peskov, 2020; Gafurov et al., 2020). The Education 2030 foresight program has developed a map of successive changes in Russian education in the context of global trends.

\section{Results and Discussion}

In April 2018, the National Research University Higher School of Economics published a report by the Centre for Strategic Research, where the problems of the Russian education system were analyzed in detail: growing educational failure; the insufficient scale of talent support; gaps in the quality of vocational education; growing inequality and such its reasons as low student involvement and significant underfunding of education from the federal and regional budgets (Report of the Centre for Strategic Research and the Higher School of Economics of the Higher School of Economics).

After the transformation of the Ministry of Education of the RF, the work on developing the strategy was divided into the directions of each of the two new ministries. In 2019, the Ministry of Enlightenment of Russia continued the development of a draft sectoral strategy for the DoE in the RF, an Interdepartmental Working Group to develop a sectoral strategy was created, which included representatives of federal executive authorities, including the Ministry of Education and Science of Russia, educational and scientific organizations, the Education and Science Employees Union of RF, professional and expert communities. It was decided to develop a draft strategy for the development of children's education in the RF, which will include the provisions of the strategy for the DoE in the RF for the period up to 2025 (Order of the Government of the Russian FedeGRFration dated May 29, 2015, No. 996-r), as well as take into 
account the national goals outlined in the Decree of the PRF, No. 204, and the provisions of the 2030 Fourth Sustainable Development Goal ("Achievement of inclusive and equitable quality education and promoting lifelong learning opportunities for all") (The Ministry of Education and Science is proposing a new program to improve the global competitiveness of universities).

The Ministry of Education and Science of Russia focused on elaborating a Strategy for the Development of Higher Education for the Long Run, taking into account the problems and challenges of our time, the need to ensure a scientific and technological breakthrough, economic growth of the country. The strategy should become part of a single document of strategic planning for the education sector as a whole.

In June 2020, a draft document of the Strategic Academic Leadership Program (The Ministry of Education and Science is proposing a new program to improve the global competitiveness of universities) was presented to the Russian Union of Rectors. The strategy is based on the axiom of the paramount importance of science and higher education for achieving the national development goals of the country, which were formulated in the Decree of the PRF dated May 7 , 2018 (Decree of the PFR of 07.05.2018 No. 204). Russia needs to become one of the five largest economies in the world due to the advanced development of innovative business focused not only on the domestic but also on the world market.

Back in 2015, 193 states, including Russia, signed the UN General Assembly Resolution "Transforming Our World: The 2030 Agenda for Sustainable Development", which outlines 17 goals, the fourth of which is dedicated to education. It is formulated as "ensuring inclusive, equitable quality education and promoting lifelong learning opportunities for all" (SDG-4) (UN General Assembly Resolution 70/1 dated 25.09.2015).

Subsequently, 10 targets and 43 indicators of sustainable development were identified, which, in turn, are divided into 11 global and 32 thematics covering all levels of education. Each country reports on these indicators, and UNESCO collects, calculates, and submits the corresponding data to the "parliament of nations". It is assumed that each country will develop, in addition to indicators of the achievement of the Sustainable Development Goals (SDGs), its own National System of Indicators, specifying a tool for monitoring progress in achieving the Sustainable Development Goals based on national priorities and taking into account the national context.

The Ministry of Enlightenment of Russia and the Ministry of Education and Science of Russia are the executive authorities responsible for the implementation of SDG-4 in the field of sustainable development for the period up to 2030. In order to prepare the Russian Voluntary National Review of Achieving Sustainable Development Goals by 2020 and development within the framework of SDG-4, a thematic working group was created; the Ministry of Enlightenment of Russia headed it, and it is responsible for the preparation and collection of statistical and analytical information in this area.

\section{Summary}

As part of the development of the latter direction, in 2020 on the website of the Russian Academy of National Economy and Public Administration (RANEPA) under the PRF, a draft document appeared for professional and public discussion "Key directions for the DRE to achieve the goals and objectives of sustainable development in the education system" until 2035 (Project "Key directions of DRE to achieve the goals and objectives of sustainable development in the education system" until 2035). This project is focused on conceptual terms on the above-mentioned international document on solving global challenges in the field of Russian education.

In accordance with the Decree of the PRF dated January 16, 2017 No. 13 "On Approval of the Fundamentals of State Policy for Regional Development of the RF for the Period up to 2025" (Decree of the PRF dated January 16, 2017 No. 13), it is necessary to solve the problem of determining the main directions of changes in the spatial structure of the Russian economy and to develop on this basis interrelated strategies of spatial development of the RF, sectoral documents of strategic planning and strategies for the socioeconomic development of macroregions, constituent entities of the RF and municipalities, as well as approval and adjustment (based on strategic planning documents developed at the federal level within the framework of goal-setting, planning and programming) of state programs of the RF, providing for the development of certain sectors of the economy and social sphere. 


\section{Conclusions}

Strategic planning is one of the ways to control the future that determines the destination of the organization and coordinates the direction of all activities towards that destination. Strategic planning, by indicating the destination and orienting towards the drawn vision, is in fact a beacon for managers who are looking for new methods in the field of vision management. If we do not have a goal to go and do not have a clear vision for the future, in other words, we do not know where we are going, it does not matter which way we go, we will certainly not reach the right destination.

In the presence of a large number of strategic documents of different levels, there is a problem of coordination: it is not entirely clear what precisely the regions should focus on when developing their strategic documents in the field of education. Today, the regions have no other way out except to take into account the entire complex of topical strategic documents of the federal level and to work point-wise with the priorities indicated in them. For example, Federal Law No. 172-FZ does not oblige municipalities to adopt strategies; this issue is left to the discretion of local government bodies (Federal Law dated June 28, 2014, No. 172-FZ). At the same time, it is not entirely clear what should determine the goals of the DoE at a municipal level in the absence of a strategy. In this case, the emphasis naturally shifts to municipal programs, which, at the same time, take into account the priorities of the regional level. The regions are adopting strategies for socioeconomic development, which envisage a sectoral block and a section "education". Sometimes they develop "concepts of the priority direction of development": a document detailing the priorities outlined in the strategy, including those concerning specific territories, sectors, and projects.

\section{Acknowledgements}

The work is performed according to the Russian Government Program of Competitive Growth of Kazan Federal University.

\section{References}

Decree of the Government of the Russian Federation dated 04.10.2000 No. 751 "On the national doctrine of education in the Russian Federation." Retrieved from https://base.garant.ru/182563/

Decree of the Government of the Russian Federation dated December 26, 2017 No. 1642 (as amended on June 4, 2020) "On approval of the state program of the Russian Federation" Development of Education ". Retrieved from http://www.consultant.ru/document/cons_doc_LAW_286474/cf742885e783e08d9387d7364e34f26f87ec138f/

Decree of the President of the Russian Federation dated December 31, 2015 No. 683 "On the National Security Strategy of the Russian Federation". Retrieved from http://www.consultant.ru/document/cons_doc_LAW_191669/

Decree of the President of the Russian Federation dated January 16, 2017 No. 13 "On Approval of the Fundamentals of State Policy for Regional Development of the Russian Federation for the Period up to 2025". Retrieved from http://docs.cntd.ru/document/420389221

Decree of the President of the Russian Federation of 07.05.2018 No. 204 "On national goals and strategic objectives of the development of the Russian Federation for the period up to 2024". Retrieved from http://static.kremlin.ru/media/acts/files/0001201805070038.pdf

Federal law dated June 28, 2014, No. 172-FZ "On Strategic Planning in the Russian Federation". Retrieved from http://www.consultant.ru/document/cons_doc_LAW_164841/

Fedorchuk, Yu. M., Neustroev, S. S., Polyaninova, Yu. V., \& Chekulaeva, Yu. A. (2017). Effective practices and innovative models for the professional development of the head of an educational organization. Moscow: Institute of Educational Management of the Russian Academy of Education, 70 p.

Gafurov, I. R, Safiullin, M. R, Akhmetshin, E. M, Gapsalamov, A. R., \& Vasilev, V. L. (2020). Change of the Higher Education Paradigm in the Context of Digital Transformation: From Resource Management to Access Control. International Journal of Higher Education, 9(3), 3-11. https://doi.org/10.5430/ijhe.v9n3p71

Ilyina, E. A., Shchiptsova, A. V., Poverinov, I. E., Grigoreva, S. V., Gorshkova, N. K., \& Fisunov, P. A.(2019). Features of the Development of the Digital Educational Environment in Russia. International Journal of Higher Education, 8(7). https://doi.org/10.5430/ijhe.v8n7p121 
Luksha, P., \& Peskov, D. The future of education: a global agenda. Retrieved from https://vbudushee.ru/upload/iblock/f47/f47425d3a3eeae0b4d37ce157f622aea.pdf

Morozov, A. V. (2018). Features of the work of the head of a general education institution with gifted and talented students. Education management: theory and practice, 3(31), 75-87.

Morozov, A. V. (2019). Development of a professional standard for a head of a general education organization as an urgent problem. In the collection of papers: Pedagogical interaction: opportunities and prospects // Materials of the I scientific-practical conference with international participation. Saratov: SSMU, 754-760.

Morozov, A. V. (2019). Prospects for the development of school education: the problem of developing and implementing a professional standard for the head of a general educational organization. In the collection of papers: Modernization of education: problems of general, secondary vocational and higher education // Materials of the XXVI Ryazan pedagogical readings / edited by L.A. Baikova, N.V. Martishina. Ryazan: RSUnamed after S.A. Yesenin, 90-95.

Morozov, A. V. (2019). Training of a creative teacher in higher education: psychological and pedagogical aspects. In the collection: Socio-cultural problems of modern higher education. Collection of scientific works. M.: RUDN, 43-47.

National educational initiative "Our New School". Retrieved from https://base.garant.ru/6744437/

Neustroev, S. S., \& Fedorchuk, Yu. M. (2018). Formation of a personnel reserve system for heads of general educational organizations. Education management: theory and practice, 1(29), 5-13

Order of the Government of the Russian Federation dated 13.02.2019 No. 207-r (as amended on 31.08.2019) "On approval of the Spatial Development Strategy of the Russian Federation for the period up to 2025". Retrieved from http://www.consultant.ru/document/cons_doc_LAW_318094/006fb940f95ef67a1a3fa7973b5a39f78dac5681/

Order of the Government of the Russian Federation dated March 29, 2019 No. 558-r "On approval of the budget forecast of the Russian Federation for the period up to 2036". Retrieved from https://www.garant.ru/products/ipo/prime/doc/72112668/

Order of the Government of the Russian Federation dated May 29, 2015 No. 996-r "On approval of the Strategy for the development of education in the Russian Federation for the period up to 2025". Retrieved from http://www.consultant.ru/law/hotdocs/43281.html/

Order of the Government of the Russian Federation dated November 17, 2008 No. 1662-r (as amended on September $28,2018)$ "On the Concept of long-term socio-economic development of the Russian Federation for the period up to 2020". Retrieved from http://www.consultant.ru/document/cons_doc_LAW_82134/404acceb6b806af7e46939aa23904acdec1df1f5/

Passport of the national project design "Education". Access mode: https://base.garant.ru/72192486/ (access date 22.02.2020)

Presidential Address to the Federal Assembly of the Russian Federation dated 15.01.2020. Retrieved from http://www.consultant.ru/document/cons_doc_LAW_342959/

Project "Key directions of development of Russian education to achieve the Goals and objectives of sustainable development in the education system" until 2035. Retrieved from http://edu2035.firo-nir.ru/index.php/stati-opublikovannye-uchastnikami-soobshchestva/86-klyuchevye-napravle niya- 2035

Report of the Centre for Strategic Research and the Higher School of Economics of the Higher School of Economics "Twelve Solutions for New Education". Retrieved from https://www.hse.ru/data/2018/04/06/1164671180/Doklad_obrazovanie_Web.pdf

Resolution of the Government of the Russian Federation dated March 29, 2019 No. 377 (as amended on March 31, 2020) "On approval of the state program of the Russian Federation "Scientific and technological development of the Russian Federation". Retrieved from https://base.garant.ru/182563/

Roadmap "Education 2030". Retrieved from https://asi.ru/news/2475/

The Ministry of Education and Science is proposing a new program to improve the global competitiveness of universities. Retrieved from https://tass.ru/obschestvo/8656279 
UN General Assembly Resolution 70/1 dated 25.09.2015 "Transforming our world: the 2030 Agenda for Sustainable Development". Retrieved from https://www.un.org/sustainable development/ru/sustainable-development-goals/

\section{Copyrights}

Copyright for this article is retained by the author(s), with first publication rights granted to the journal.

This is an open-access article distributed under the terms and conditions of the Creative Commons Attribution license (http://creativecommons.org/licenses/by/4.0/). 